\title{
Analyzing Motor Development and Emergent Literacy Skills of Preschool Children
}

\author{
Fatma Özkür ${ }^{1}$ \\ ${ }^{1}$ Nişantaşı University, Nişantaşı Vocational High School, Istanbul, Turkey \\ Correspondence: Fatma Özkür, Nişantaşı University, Nişantaşı Vocational High School, Istanbul, Turkey. E-mail: \\ fatmaoz.edu@gmail.com
}

Received: December 6, 2019

Accepted: January 10, $2020 \quad$ Online Published: March 9, 2020

doi:10.5539/ies.v13n4p94

URL: https://doi.org/10.5539/ies.v13n4p94

\begin{abstract}
Children start to gain basic literacy skills during preschool that they will constantly be depended on for their academic activities in primary school. Through learning shoulder girdle strength, fine motor skills, and eye-hand coordination, the foundation of motor skills is developed. Examining the effects of motor skills on emergent literacy skills could provide helpful information on the associations among motor and, reading and writing development. The purpose of this study was to analyze 5 years old children's motor development and emergent literacy skills. The sample of the study consisted of 160 preschool children from main district of Istanbul. Dumans TMB scale and OYHB scale was used for data collection purposes. Results showed that majority of the preschool children (68\%) participated in the study had insufficient level of emergent literacy skills. This group's motor development score was also significantly lower than instructional group. Pearson correlation analysis showed that there was a positive and medium level correlation between the scores of motor development and emergent literacy in both groups. It has been suggested that preschool children's motor skills should be taken into account for their emergent literacy skills development.
\end{abstract}

Keywords: preschool, motor development, emergent literacy, children

\section{Introduction}

Preschool education refers to the period from the birth of the child to the start of primary school. This education plays an important role in the later life of the children. Because their physical, psychomotor, social, emotional, cognitive, and language developments are monitored and supported. Teachers have a great impact on children during this period. They organize educational activities that children can discover and improve their physical, cognitive, social-emotional, language and self-care skills. Preschool children start to build their skills in these activities and they will use these skills for the rest of their life. When children miss these activities during the early years, it's likely they come to a few steps behind their peers in primary school.

Motor development indicates physical skills that use body movements. These movements are examined as large motor and fine motor skills. Like all adults, children use large motor skills for large body movements. They use fine motor skills for smaller and strict movements. Most of these movements combine hand and finger manipulation (Duman, 2015). Comparing to large motor skills, fine motor skills require better precision (Boz, 2015). As of motor movements, preschool children at the age of 5 can go up and down the stairs alone. They start to run smoothly and increase their speed. They also start to have more control in activities such as riding their tricycles or playing ball games. As their development continues, they refine earlier skills. Their large motor skills support them to involve in new forms of physical play such as the jungle gym, totter, slide, and swing on their own. Even though they are still discovering new forms of movement, they also continue to improve their large motor skills. Five years old children also continue to progress their fine motor skills as well (Özkür, 2019). They can wear their clothes, tie their shoes, brush their teeth, comb their hair, and eat independently. Besides, they can duplicate letters and shapes, and draw simple figures. As they master in fine motor skills, they will be able to use paints, crayons and pencils with better control (Purtaş \& Duman, 2017).

Studies showed that becoming advanced in motor development and physical activities is related to movement experiences gained in infancy, adolescence and adulthood (Ridgway et al., 2009; Okely et al., 2011). For the development of basic mobility skills, children between the ages of two and seven should be provided with rich stimulants and appropriate educational opportunities (Gallahue \& Ozmun, 2006). Preschool children with better 
motor skills involve in more diverse activities (Wrotniak et al., 2006; Fisher et al., 2005). This advantage provides them different social interactions resulting in gaining better social skills as well (Özkür, 2019). Past movement experiences become the foundation for interactions and progress in subsequent motor development periods. Consequently, motor proficiency is the result of a long process of development that involves active participation in appropriate developmental activities of the child (Clark, 2007; Barela, 2013). Motor skills lead to the successful exploration of the environment by infants, and infants construct their knowledge of the world through such behavior (Piaget, 1952). Studies have shown that the experiences of children with self-produced locomotion are related to cognitive abilities such as the permanence of objects and spatial information organization (Bertenthal, Campos, \& Kermoian, 1994; Campos et al., 2000). Advances in neuropsychology also provide knowledge based on brain function and structure about the relationship between motor skills and cognition. When we consider the literacy capabilities of reading and writing, they are structured from cognitive abilities such as visual, phonological and semantic systems (Son \& Meisels, 2006). Thus, challenges in literacy skills can be the result of poor conditions observed in other systems that writing and reading skills are emerged (Rosenbaum, Carlson, \& Gilmore, 2001).

Preschool children are instructed to acquire basic reading and writing literacy skills during preschool education. Literacy skills provide the basis for the achievement of primary school curriculum objectives. Reading skills can be defined as the analysis of given codes by the individual (Koçak, 2019). For effective reading, the symbols that structure the writing must be analyzed by the child. The meaning is formed in the mind of the child and this meaning should be accurate. The function of the emergent literacy activities of preschool education is to courage children's language, reading and writing skills. It has been stated that these skills increase the readiness of the child for primary education (Koçak, 2018). Skill development includes hand-eye coordination, shape-ground separation, shape stability, location in space, and spatial relations. Motor development plays an important role to develop these competencies. The foundation of motor skills is developed through learning shoulder girdle strength, fine motor skills, and eye-hand coordination (Dere, 2019). Thinking the significance of writing and reading literacy skills and their potential relations to motor development, both growing domains of children should be examined. Examining the effects of motor skills on emergent literacy skills could provide helpful information on the associations among motor and, reading and writing development.

\section{Method}

This research is a relational screening model describing preschool children's motor skills development and emergent literacy skill levels. Relational screening model aims to identify past or present conditions as they occur. There is no attempt to change the conditions in the sample or to affect them. The associations detected by screening were relatively interpreted rather than a cause-and-effect relationship (Karasar, 2018). In this study, preschool children's motor and emergent literacy skill development levels were related using correlation values.

\subsection{Population and Sampling}

The sample of the study consisted of children attending preschool in İstanbul city, Turkey. The sample collection process was purposeful sampling. First, six preschools were randomly selected from voluntary preschools located in the central district of Istanbul. Then, preschool children were selected in terms of being five years old age group, having average socio-economic class and gender equivalence. A total of 160 children ( 80 girls and 80 boys) were randomly selected.

\subsection{Data Collection Tools}

Dumans TMB Fundamental Motor Skills Scale (Duman, 2019) was used to collect data concerning children's motor development levels. TMB scale consisted of two sub-dimensions: large motor skills and fine motor skills. The scale consisted of 47 items including 28 items in the large motor dimension and 19 items in the fine motor dimension. The accurate skills coded as 1 and skills that not acquired yet coded as 0 . A total of 47 points can be achieved by a participant. Dumans OYHB Emerging Reading and Writing Skills Scale (Duman \& Koçak, 2019) was used to collect data concerning children's reading and writing skill levels. OYHB scale consisted of five sub-dimensions: in-hand manipulation, auditory perception, vocabulary, speaking and listening, and awareness of reading and writing. The scale consisted of 22 items. The accurate skills coded as 1 and skills that not acquired yet coded as 0 . A total of 22 points can be achieved by a participant.

\subsection{Data Collection and Analysis}

Data was collected using the scales given above. As data collection procedure of the TMB and OYHB scales, each child was observed twice during free playtimes. They also took the test separately and tried to complete the given subjects. Teacher opinions were taken for the required items. Collected data were analyzed using SPSS (22.0). Descriptive results were presented using mean scores and standard deviations. The t-Test $(p<0.05)$ was used to 
analyze the significant differences in children's reading and writing skill levels. Pearson Correlation Coefficient Test $(p<0.05)$ was conducted to analyze the correlation between motor skill and reading and writing skill values.

\section{Results}

The purpose of this study was to analyze the emergent literacy skill and motor development levels of preschool children. Descriptive and correlational results regarding emergent literacy and motor development of children were given below.

Table 1. Emergent literacy skill levels of preschool children

\begin{tabular}{lll}
\hline Group & $\mathrm{f}$ & $\%$ \\
\hline Insufficient level & 108 & 68 \\
Instructional level & 52 & 32 \\
Total & 160 & 100 \\
\hline
\end{tabular}

Table 1 presents the emergent literacy levels of preschool children. It has been found that 108 children (68\%) were in the insufficient level and 52 students (32\%) were in the instructional level of emergent literacy skill development. Results showed that the number of the children in the insufficient level was higher than the instructional level. It can be stated that preschool children's emergent literacy skill development should be encouraged during their education.

Table 2. Descriptive analysis of emergent literacy skills of preschool students

$p<0.05$.

\begin{tabular}{ccccc}
\hline Emergent Literacy Skill & $\mathrm{n}$ & $\bar{x}$ & $\mathrm{sd}$ & $\mathrm{t}$ \\
\hline Insufficient Level & 108 & 8.58 & 3.47 & $.00^{*}$ \\
Instructional Level & 52 & 11.64 & 3.76 & \\
\hline
\end{tabular}

Table 2 presents insufficient and instructional emergent literacy skill level children's arithmetic mean, standard deviation and t-Test values. It has been found that insufficient level of children's arithmetic mean score was 8.58 while instructional level children's was 11.64. Results indicated that the instructional level of children had significantly $(p<0.05)$ better emergent literacy skills comparing to the insufficient level of children.

Table 3. Motor development of emergent literacy skill level groups

$p<0.05$.

\begin{tabular}{ccccc}
\hline Motor Skill & $\mathrm{n}$ & $\bar{x}$ & $\mathrm{sd}$ & $\mathrm{t}$ \\
\hline Insufficient Level & 108 & 17.14 & 3.47 & $.00^{*}$ \\
Instructional Level & 52 & 19.47 & 3.76 & \\
\hline
\end{tabular}

Table 3 presents insufficient and instructional emergent literacy skill level of children's arithmetic mean, standard deviation and t-Test values of motor skill development. It has been found that insufficient level children's arithmetic mean score of motor development was 17.14. Instructional level children's arithmetic mean score of motor development was 19.47. Results indicated that instructional level children of emergent literacy had significantly $(p<0.05)$ higher motor development score. It can be stated that children who had better on emergent literacy test also had better scores on motor development test.

Table 4. Pearson correlation scores of emergent literacy skills and motor development

$p<0.05$.

\begin{tabular}{ccc}
\hline & Insufficient Level & Instructional Level \\
\hline Motor development & $.67 *$ & $.59^{*}$ \\
\hline
\end{tabular}

Table 4 presents the correlation values of insufficient and instructional emergent literacy level children's motor 
development. Correlation analysis pointed out that there was a positive and moderate degree correlation between motor development and insufficient emergent literacy level group of children $(r=.67)$. It also has been found that there was a positive and moderate degree correlation between motor development and instructional emergent literacy level group of children $(r=.59)$. It can be stated that both insufficient and instructional level groups of children's motor skills development scores have a correlation with emergent literacy skills development scores.

\section{Discussion}

Preschool education is a crucial period for children to develop their motor and literacy skills. The educational activities that children are experienced during this education, structure the foundations of the motor and literacy skills. Gaining these skills and competencies improve their readiness for primary school. There is a connection between motor and emergent literacy skills. Insufficiencies in one of these developmental areas can affect children's reading and writing. Preschool education aims to support these areas using educational activities and children's games. Therefore, the quality of these activities is imperative for skill development. Examining the effects of motor skills on emergent literacy skills could provide helpful information on the associations among motor and, reading and writing development. This study examined the motor development and emergent literacy skills of preschool children. The correlation between emergent literacy skills and motor development was also investigated. It has been found that $68 \%$ of the five years old preschool children participated in the research were in the insufficient level group of emergent literacy. $32 \%$ of them were in the instructional level group of emergent literacy. Results showed that most of these preschool children needed to be supported to increase their emergent literacy skills. On the other hand, the children at the instructional level had better scores on the motor development test. However, both insufficient and instructional level children had a positive and moderate degree correlation between motor development and emergent literacy skills. It can be concluded that both large and fine motor skills should be supported to increase the efficiency of the emergent literacy activities in preschool.

Earlier studies have shown similar results that confirm most of this study's findings. It has been proven that motor development supports children's object manipulation skills (Boz, 2011) and has a positive effect on drawing and folding skills (Ulutaş, Demir, \& Yayan, 2017). Besides, studies indicated that children with better motor development show better tripod grasp skills and drawing horizontal, vertical and curved lines (Goodway \& Branta, 2003; Çelebioğlu, 2011). It has been studied that visual motor coordination also plays an eminent role in children's print awareness and reading (Dere, 2019; Çayır, 2017). The development of visual-motor coordination is depended on repeated motor movements. Each learned motor movement becomes a precise basis for visual motor coordination. Therefore, motor development is required for preschool children's print awareness and reading.

The results of the study suggest that motor skills development is one of the valued components to encourage preschool children's emergent literacy skills. Emergent literacy skills of preschool children are quite valuable for their success in their primary education. It has been stated in the early childhood education program that preschool education aims to prepare children for primary school (MEB, 2013). Therefore, consideration should be given to the large and fine motor development of preschool children to be able to improve their emergent literacy skills.

\section{References}

Barela, J. A. (2013). Fundamental motor skill proficiency is necessary for children's motor activity inclusion. Motriz, 19(3), 548-51. https://doi.org/10.1590/S1980-65742013000300003

Bertenthal, B. I., Campos, J. J., \& Kermoian, R. (1994). An epigenetic perspective on the development of self-produced locomotion and its consequences. Current Directions in Psychological Science, 3(5), 140-145. https://doi.org/10.1111/1467-8721.ep10770621

Boz, M. (2011). 5-6 yaş grubu çocuklara uygulanan temel hareket eğitim programının hareket becerilerinin gelişimine etkisi. Yayımlanmamış Doktora Tezi, Gazi Üniversitesi Eğitim Bilimleri Enstitüsü, Ankara.

Boz, M. (2015). Motor gelişim (içinde: Okul öncesi dönemde beden eğitimi, Ed. G. Duman). Ankara: Hedef.

Campos, J. J., Anderson, D. I., Barbu-Roth, M. A., Hubbard, E. M., Hertenstein, M. J., \& Witherington, D. (2000). Travel broadens the mind. Infancy, 1(2), 149-219. https://doi.org/10.1207/S15327078IN0102_1

Çayır, A. (2017). Analyzing the Reading Skills and Visual Perception Levels of First Grade Students. Universal Journal of Educational Research, 5(7), 1113-1116. https://doi.org/10.13189/ujer.2017.050704

Çelebioğlu, M. Ö. (2011). 4-5 yaş grubu çocuklarına yönelik hazırlanan erken müdahale programının etkililiğinin belirlenmesi: Çanakkale ili örneği. Yayımlanmış Yüksek Lisans Tezi, Çanakkale Onsekiz Mart Üniversitesi, Sosyal Bilimler Enstitüsü, Çanakkale.

Clark, J. E. (2007). On the problem of motor skill development. JOPERD, 78(5), 39-45. 
https://doi.org/10.1080/07303084.2007.10598023

Dere, Z. (2019). Analyzing the early literacy skills and visual motor integration levels of kindergarten students. Journal of Education and Learning, 8(2), 176-181. https://doi.org/10.5539/jel.v8n2p176

Duman, G. (2015). Okul öncesi eğitimde beden eğitimi ve oyun. Ankara: Eğiten.

Duman, G. (2019). Temel motor beceriler değerlendirme ölçeği: Geçerlik ve güvenirlik çalışmaları. SADAB Inter. Soc. Res. and Beh. Sci. Symp. Proceeding Book (pp. 323-328). Antalya.

Duman, G., \& Koçak, M. (2019). Okuma yazmaya hazırlık becerileri derecelendirme ölçeği: Geçerlik ve güvenirlik çalışmaları. SADAB Inter. Soc. Res. and Beh. Sci. Symp. Proceeding Book (pp. 313-317). Antalya.

Fisher, A., Reilly, J. J., Kelly, L. A., Montgomery, C., Williamson, A., Paton, J. Y., \& Grant, S. (2005). Fundamental movement skills and habitual physical activity in young children. Medicine \& Science in Sports \& Exercise, 37(4), 684-688. https://doi.org/10.1249/01.MSS.0000159138.48107.7D

Gallahue, D., \& Ozmun, J. (2006). Understanding motor development. New York: McGraw-Hill.

Goodway, J. D., \& Branta, C.F. (2003). Influence of a motor skill intervention on fundamental motor skill development of disadvantaged preschool children. Research Quarterly For Exercise and Sport, 74(1), 36-46. https://doi.org/10.1080/02701367.2003.10609062

Karasar, N. (2018). Bilimsel araştırma yöntemleri. Ankara: Nobel.

Koçak, M. (2018). Okul öncesi eğitimde uygulanan okuma yazmaya hazırlı etkinlik planlarının incelenmesi. Yüksek Lisans Tezi, Gazi Üniversitesi, Eğitim Bilimleri Enstitüsü, Ankara. https://doi.org/10.31576/smryj.411

Koçak, M. (2019). Anaokulu çocuklarinin okuma yazmaya hazırlık becerileri ile dil gelişimleri arasındaki ilişkinin incelenmesi. SADAB Inter. Soc. Res. and Beh. Sci. Symp. Proceeding Book (pp. 829-833). Antalya.

MEB. (2013). Okul öncesi eğitim programı. MEB Temel Eğitim Genel Müdürlüğü.

Okely, A. D., Booth, M. L., \& Patterson, J. W. (2001). Relationship of physical activity to fundamental movement skills among adolescents. Medicine and Science in Sports and Exercise, 33(11), 1899-1904. https://doi.org/10.1097/00005768-200111000-00015

Özkür, F. (2019). Anaokulu çocuklarının görsel-motor koordinasyon seviyeleri ile sosyal beceri gelişimleri arasındaki ilişkinin incelenmesi. SADAB Inter. Soc. Res. and Beh. Sci. Symp. Proceeding Book (pp. 339-343). Antalya.

Piaget, J. (1952). The origins of intelligence in children. New York: International Universities press. https://doi.org/10.1037/11494-000

Purtaş, Ö., \& Duman, G. (2017). The examination of movement activity plans applied in early childhood education in terms of various variables. Turkish Journal of Primary Education, 2(1), 11-29.

Ridgway, C. L., Ong, K. K., Tammelin, T. H., Sharp, S., Ekelund, U., \& Jarvelin M. R. (2009). Infant motordevelopment predicts sports participation at age 14 years: Northern Finland birth cohort of 1966. PLOS ONE, 4(8). https://doi.org/10.1371/journal.pone.0006837

Rosenbaum, D. A., Carlson, R. A., \& Gilmore, R. O. (2001). Acquisition of intellectual and perceptual-motor skills. Annual Review of Psychology, 52, 453-470. https://doi.org/10.1146/annurev.psych.52.1.453

Son, S. H., \& Meisels, S. J. (2006). The relationship of young children's motor skills to later reading and math achievement. Merrill-Palmer Quarterly, 52, 755-778. https://doi.org/10.1353/mpq.2006.0033

Stodden, D., Langendorfer, S., \& Roberton, M. A. (2009). The association between motor skill competence and physical fitness in young adults. Research Quarterly for Exercise and Sport, 80(2), 223-229. https://doi.org/10.1080/02701367.2009.10599556

Ulutaş, A., Demir, E. \& Yayan, E.H. (2017). Motor gelişim eğitim programının 5-6 yaş çocukların kaba ve ince motor becerilerine etkisinin incelenmesi. Abant İzzet Baysal Üniversitesi Eğitim Fakültesi Dergisi, 17(3), 1523-1538. https://doi.org/10.17240/aibuefd.2017.17.31178-338846

Wrotniak, B. H., Epstein, L. H., Dorn, J. M., Jones, K. E., \& Kondilis, V. A. (2006). The relationship between motor proficiency and physical activity in children. Pediatrics, 118(6), e1758-e1765. https://doi.org/10.1542/peds.2006-0742 


\section{Copyrights}

Copyright for this article is retained by the author(s), with first publication rights granted to the journal.

This is an open-access article distributed under the terms and conditions of the Creative Commons Attribution license (http://creativecommons.org/licenses/by/4.0/). 